\title{
Seasonal home ranges and fidelity to breeding sites among ringed seals
}

\author{
Brendan P. Kelly • Oriana H. Badajos • Mervi Kunnasranta • \\ John R. Moran - Micaela Martinez-Bakker · Douglas Wartzok • \\ Peter Boveng
}

Received: 17 November 2009/Revised: 19 February 2010/Accepted: 15 March 2010/Published online: 11 April 2010

(C) The Author(s) 2010. This article is published with open access at Springerlink.com

\begin{abstract}
Population structure and patterns of habitat use among ringed seals (Phoca hispida) are poorly known, in part because seasonal movements have not been adequately documented. We monitored the movements of 98 ringed seals in the Beaufort and Chukchi seas between 1990 and 2006 using three forms of telemetry. In the winter-spring
\end{abstract}

B. P. Kelly $(\bowtie) \cdot$ O. H. Badajos · M. Kunnasranta ·

J. R. Moran · M. Martinez-Bakker

Department of Natural Sciences, University of Alaska Southeast, Juneau, AK 99801, USA

e-mail: brendan.kelly@noaa.gov

Present Address:

B. P. Kelly

National Marine Mammal Laboratory, Alaska Fisheries Science Center, National Marine Fisheries Service, NOAA, 17109 Point Lena Loop Road, Juneau, AK 99801, USA

O. H. Badajos

Kachemak Bay Research Reserve, 95 Sterling Hwy., Suite 2, Homer, AK 99603, USA

\section{Kunnasranta}

Finnish Game and Fisheries Research Institute, Turku Game and Fisheries Research, Itäinen Pitkäkatu 3, 20520 Turku, Finland

\section{J. R. Moran}

Auke Bay Laboratories, Alaska Fisheries Science Center, National Marine Fisheries Service, NOAA, 17109 Point Lena Loop Rd, Juneau, AK 99801, USA

D. Wartzok

Florida International University, University Park PC 526,

Miami, FL 33199, USA

\section{P. Boveng}

National Marine Mammal Laboratory, Alaska Fisheries Science Center, National Marine Fisheries Service, NOAA, 7600 Sand Point Way, NE, Seattle, WA 98115-6349, USA period (when the seals were occupying shorefast ice), we used radio and ultra-sonic tags to track movements above and below the ice, respectively. We used satellite-linked transmitters in summer and fall (when the seals ranged away from their winter sites) to track at-sea movements. In the shorefast ice habitat, the home ranges of 27 adult males ranged from $<1$ to $13.9 \mathrm{~km}^{2}$ (median $=0.628$ ) while the home ranges of 28 adult females ranged from $<1$ to $27.9 \mathrm{~km}^{2}$ (median $=0.652$ ). The 3 -dimensional volumes used by 9 seals tracked acoustically under the ice averaged $0.07(\mathrm{SD}=0.04) \mathrm{km}^{3}$ for subadults and adult males and $0.13(\mathrm{SD}=0.04) \mathrm{km}^{3}$ for adult females. Three of the radio-tracked seals and 9 tracked by satellite ranged up to $1,800 \mathrm{~km}$ from their winter/spring home ranges in summer but returned to the same small $\left(1-2 \mathrm{~km}^{2}\right)$ sites during the ice-bound months in the following year. The restricted movements of ringed seals during the ice-bound seasonincluding the breeding season-limits their foraging activities for most of the year and may minimize gene flow within the species.

Keywords Phoca hispida $\cdot$ Home range · Population structure $\cdot$ Site fidelity $\cdot$ Movements

\section{Introduction}

The seasonal movements and population structure of ringed seals (Phoca hispida) have been little studied, in part because of the species' wide range encompassing a difficult environment, the seasonally ice-covered seas (and some freshwater lakes) of the Northern Hemisphere (McLaren 1958; Reeves 1998; Born et al. 2004). Inuit and other northern people have long known that ringed seals occupy seasonal sea ice from the time of ice formation in the fall 
through the break-up of the shorefast ice the following summer (Boas 1888; Taylor 1968; Cox and Spiess 1980; Sabo and Jacobs 1980). The ringed seals' use of breathing holes that they abrade in the ice using their claws and lairs that they excavate in the overlying snow permits them to remain in areas of otherwise solid ice cover throughout the winter and the spring, including the breeding season (April-June for the Arctic Ocean populations) when they give birth and suckle their young under the snow (Hall 1866; Chapskii 1940; McLaren 1958). Inuit hunters and field biologists inferred movements of seals based on the distribution of breathing holes and lairs (McLaren 1958; Smith and Stirling 1975). Direct evidence of movements during the spring months was first provided by radio tracking studies (Kelly and Quakenbush 1990). Subsequent tracking suggested that Arctic ringed seals ranged over wide areas in summer (Heide-Jørgensen et al. 1992; Kelly 1996; Kapel et al. 1998; Ridoux et al. 1998; Teilmann et al. 1999; Born et al. 2004; Freitas et al. 2008a) consistent with the suggestion that interbreeding takes place over large areas (Scheffer 1958; King 1983; Davis 2004; Davis et al. 2008). Ringed seals inhabiting the Baltic Sea and Lake Saimaa in Finland, however, do not make long distance movements; instead, they exhibit strong fidelity to particular sites (Hyvärinen et al. 1995; Härkönen et al. 1998, 2008; Kunnasranta 2001; Koskela et al. 2002). Here, we report on the extent of seasonal movements by Arctic ringed seals.

Better knowledge of the ringed seals' seasonal movements and patterns of habitat use are important for understanding their relationships to (1) polar bears (Ursus maritimus) and other predators, (2) expanding industrial development, and (3) rapid environmental change, especially the decreasing duration of seasonal snow and ice cover (Kelly 1988, 2001; Tynan and DeMaster 1997; Stirling and Smith 2004; Ferguson et al. 2005; Freitas et al. 2008b).

Ringed seals have frequently been described (e.g., McLaren 1958; Burns 1970) as showing a preference for shorefast sea ice or occurring in higher densities there than in the moving pack ice. Many breeding ringed seals, however, do occupy pack ice (Finley et al. 1983; Wiig et al. 1999; Bengtson et al. 2005), and some researchers in Canada and Alaska report that densities differ more with distance from shore than with ice type (Smith 1973; Bengtson et al. 2005). Nonetheless, for logistical reasons, our study focused on seals breeding in shorefast sea ice.

Arctic ringed seals rest, give birth, nurse their young, and molt on seasonal sea ice. In winter and spring, they feed under the ice, and in summer and early fall, they feed either in open water or under ice. Thus, we divided our investigation of movements and habitat use into three time periods; the subnivean period (when ringed seals give birth and nurse their young), the basking period (when epidermal tissue is shed and regenerated), and the foraging period (when feeding occurs over wide areas).

\section{Materials and methods}

We refer to the subnivean period as the period in early winter through mid-May to early June when seals in our study areas rested on the ice, primarily in subnivean lairs. Lairs likely are excavated as soon as sufficient snow has accumulated on the ice and have been documented as early as January (Smith et al. 1991). Our investigation of activity in the subnivean period focused on April to mid-June, a time that is especially important to reproductive success as it is then that the pups are born and nursed.

Between abandonment of the lairs in May or June and ice break-up (typically in July in our study areas), ringed seals rested on the ice without cover. At that time, direct exposure to solar radiation is important to achieving the elevated skin temperatures necessary for epidermal (skin and hair) regeneration (Feltz and Fay 1966). We refer to the period between lair abandonment and ice break-up as the basking period.

From ice break-up to the subsequent freeze-up in fall, ringed seals forage more intensively than at other times (Lowry et al. 1980; Ryg et al. 1990; Weslawski et al. 1994) and are less frequently observed out of the water. We refer to that period as the foraging period with the recognition that ringed seals-in contrast to most species of phocid seals (Costa 1991; Schulz and Bowen 2005)—also forage during lactation while occupying subnivean lairs (Kelly and Wartzok 1996; Lydersen and Kovacs 1999).

Our study of ringed seal movements and habitat use relied on three types of data:

1. on-ice resting locations in the subnivean and basking periods-primarily April, May, and June-determined by tracking seals equipped with VHF radio transmitters,

2. under-ice movements in those periods, determined by tracking seals acoustically, and

3. movements throughout the year-including during the foraging period-determined by tracking seals equipped with satellite-linked transmitters.

Ringed seals were captured during April, May, and early June in Resolute Bay, Canada (1990, 1991, 1992, 1996, and 1997); Prudhoe Bay, Alaska (1999, 2000, 2001, 2002, and 2003); Peard Bay, Alaska (2005 and 2006); the Canadian Beaufort Sea, Canada (2006), and Kotzebue Sound, Alaska (2007) (Fig. 1). Seals were captured within $15 \mathrm{~km}$ of shore in all sites except the Canadian Beaufort Sea where captures were $50 \mathrm{~km}$ north of Garry Island. The 


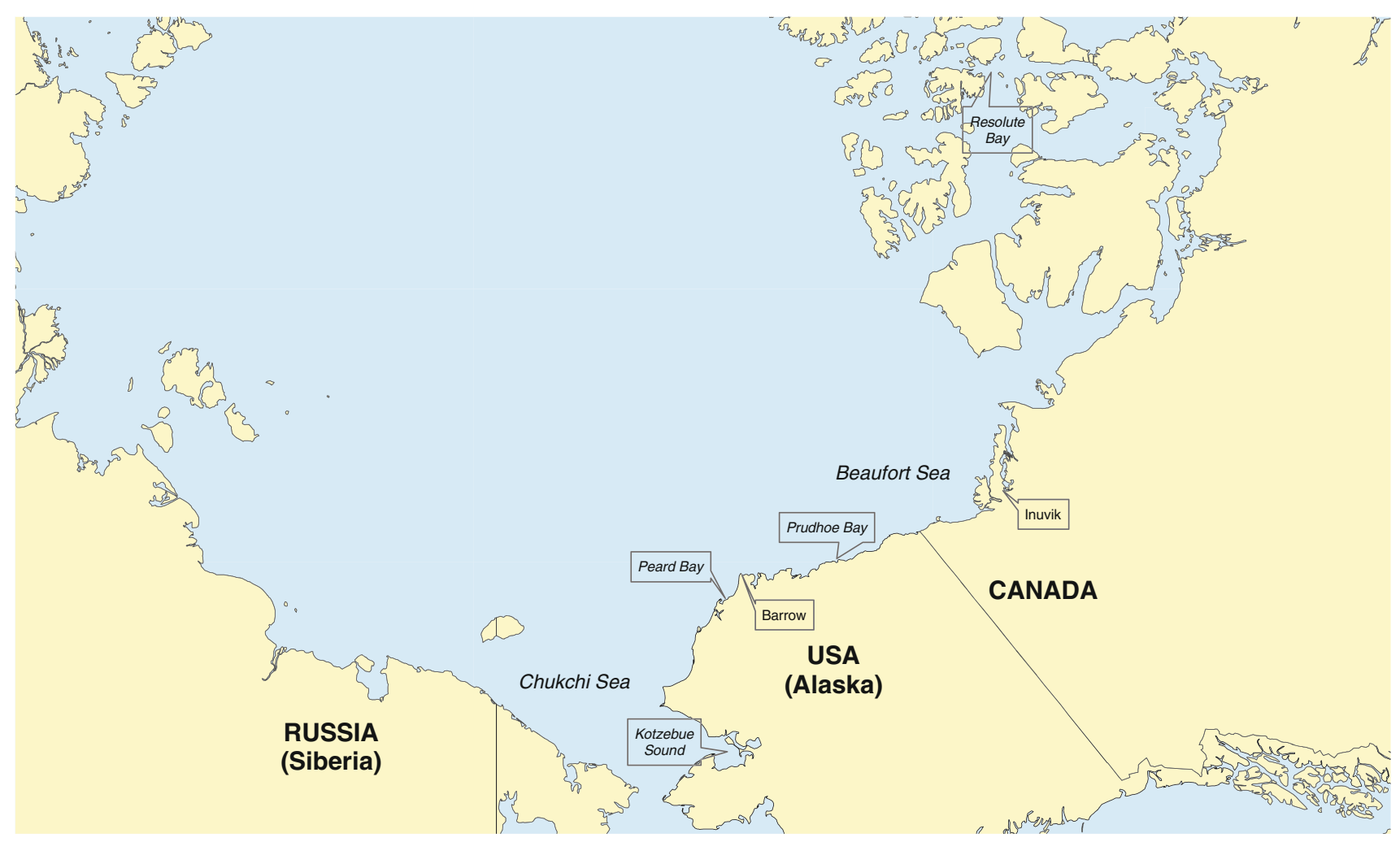

Fig. 1 Arctic Ocean study sites

breathing holes and subnivean lairs were located by dogs trained to alert us to the odor of ringed seals (Smith and Stirling 1975; Kelly and Quakenbush 1987). Seals were live-captured in breathing holes using a remotely triggered version of the net described by Kelly (1996). We estimated the minimal age of seals by counting annuli on the claws of the forelimbs (McLaren 1958). The annuli wear away at the distal end of the claws, but they persist sufficiently long to distinguish immature from mature seals.

We captured 60 ringed seals near Prudhoe Bay, Alaska $\left(70^{\circ} 29^{\prime} \mathrm{N}, 148^{\circ} 21^{\prime} \mathrm{W}\right)$ and determined the on-ice resting location of 58 of those seals by radio tracking. The transmitters failed on 2 of the seals preventing us from relocating them. We glued a $26 \mathrm{~g}$ VHF radio transmitter (Advanced Telemetry Systems, model MM170) ${ }^{1}$ with a unique frequency to the hair on each seal's back. To extend our observations of seal haul-out bouts (time spent out of the water) and movements beyond the annual molt, we attached a second $23 \mathrm{~g}$ VHF radio transmitter (Advanced Telemetry Systems, model MM420) to one hindflipper of each seal by way of a cattle ear tag (Temple Tag, Inc., Model 73200) in 2002 and 2003.

\footnotetext{
${ }^{1}$ Reference to trade names does not imply endorsement by the National Marine Fisheries Service, NOAA.
}

We monitored radio signals hourly ( $24 \mathrm{~h}$ per day) from stations equipped with 8-element Yagi antennas on $11 \mathrm{~m}$ high masts within $5 \mathrm{~km}$ of the seal capture sites. We rotated the antenna through $360^{\circ}$ while monitoring and recording the direction from which each signal was received. Each time a seal came out of the water, as indicated by the presence of its radio signal, we determined its location using a mobile receiver and hand-held directional antenna array. The directional antenna array consisted of two Yagi antennas communicating with the acoustic receiver by way of a null combiner. Thus, the bearing from the array to a transmitter was indicated by a null surrounded by high amplitude signals. Typically, five or more bearings (with an accuracy of approximately $\pm 3^{\circ}$ ) were obtained from points surrounding a tagged seal, and the seal's position was read as the intersection of those bearings. Once the seal's position was determined, we recorded whether each seal was concealed within a lair or visible on the ice surface. Individual seals were monitored for up to 55 days (a total of 1,272 seal-days) during the subnivean period and up to 53 days (a total of 1,405 seal-days) during the basking period.

The locations of subnivean lairs and basking sites (sites where seals rested on the ice without snow cover) used by the tagged seals were plotted using MapSource (Garmin Corporation), transferred to an ArcView shape file (ESRI, 
Inc.), and the two-dimensional home ranges were delineated as minimum convex polygons (Mohr 1947; Rurik and Macdonald 2003) using "AlaskaPak," an extension for ArcView 3.x. All locations forming the polygons were used to calculate home range sizes. The estimates did not account for water (or ice) depth, which did not exceed $9 \mathrm{~m}$ in any of the areas used by seals in this portion of the study.

Diel patterns of haul-out bouts were examined over periods ranging from 22 to 52 days for each tagged seal. The frequency distributions of haul-out bouts at each hour of the day were plotted and the circular mean and standard deviations were calculated (Batschelet 1981). The frequency and duration of haul-out bouts were examined separately for haul-out bouts in lairs and haul-out bouts at basking sites. The probability that the timing of haul-out bouts was the same when seals were in lairs and when they were basking was tested using Watson's $U^{2}$ statistic (Batschelet 1981). Rao's Spacing Statistic ( $U$ ) was used to evaluate deviations from uniformity in the times at which seals were out of the water (Batschelet 1981).

Thirteen seals were tracked under the ice in Resolute Passage, Canada $\left(74^{\circ} 35^{\prime} \mathrm{N}, 95^{\circ} 7^{\prime} \mathrm{W}\right)$, where the water depth reached $225 \mathrm{~m}$. Ultrasonic transmitters (Model V3P-5HI and V3/V4P-8HI-CPU, VEMCO Ltd., Armdale, Nova Scotia, Canada) glued to each seal broadcast at unique frequencies $(50-75 \mathrm{kHz})$ received via an array of four hydrophones (VEMCO Ltd.) suspended under the ice (Wartzok et al. 1992; Kelly and Wartzok 1996; Simpkins et al. 2001). A time difference of arrival algorithm displayed and recorded the three-dimensional position of each seal at 1-2 s intervals (Wartzok et al. 1992). Nine of the seals tracked under the ice (two adult males, three adult females, and five immature seals) were tracked continuously for 7-30 days. The three-dimensional, under-ice home ranges of those seals were calculated as convex hulls, the smallest convex set that contained all of the locations occupied (Barber et al. 1996).

We measured overlap in under-ice ranges in four instances when we tracked two ringed seals within the same area and time. We sampled the three-dimensional locations of those seals at 10-min intervals (sufficient time for them to swim to any point in their under-ice home range) and then grouped the observations into $200 \times 200 \times 50 \mathrm{~m}$ blocks. The size and shape of the blocks were chosen to ensure that most cells contained some locations while not obscuring the shape of the home range (Doncaster 1990). For each pair of seals tracked within a single hydrophone array, we recorded the percentage of blocks visited by a seal that was also visited by the other seal.

To track movements throughout the year, we attached satellite-linked transmitters (Wildlife Computers, SPOT4 or SPOT5 tags) to the hindflippers of 25 ringed seals captured in the breeding season in 2005, 2006, and 2007 (Table 1). The transmitters were attached to the webbing of the flipper by way of cattle ear tags (Temple tag). We limited data transmissions from the tags to location information and activity cycles (hourly percent time in, vs. out of, the water) in order to maximize longevity of the tags as our primary interest was in determining movements between successive breeding seasons. Data were transmitted only when ARGOS satellites were overhead and when the seals were out of the water. Conductivity switches turned the transmitters off while in the water. Tags were placed on six adult male, one subadult male, and nine adult female ringed seals along the Chukchi Sea coast of Alaska $\left(70^{\circ} 49^{\prime} 12^{\prime \prime} \mathrm{N} 158^{\circ} 18^{\prime} 0^{\prime \prime} \mathrm{W}\right)$ in April and May 2005 and 2006; on four adult male and three adult female ringed seals in the Canadian Beaufort Sea $\left(69^{\circ} 38^{\prime} 24^{\prime \prime} \mathrm{N} 136^{\circ} 30^{\prime}\right.$ $0^{\prime \prime} \mathrm{W}$ ) in March 2006; and on one adult and one subadult male ringed seal in Kotzebue Sound, Chukchi Sea, Alaska $\left(66^{\circ} 45^{\prime} 36^{\prime \prime} \mathrm{N} 162^{\circ} 32^{\prime} 24^{\prime \prime} \mathrm{W}\right)$ in May 2007.

Table 1 Dates of first and last locations received from 25 ringed seals tracked by satellite in 2005-2007

\begin{tabular}{|c|c|c|c|c|}
\hline Seal & Capture site & Age/sex & First location & Last location \\
\hline VK & Peard Bay & Ad. 우 & 01 May 2005 & $21 \mathrm{Jul} 2005$ \\
\hline LY & Peard Bay & Ad. $q$ & 03 May 2005 & 22 Jan 2006 \\
\hline AS & Peard Bay & Ad. + & 25 May 2005 & 15 Mar 2006 \\
\hline $\mathrm{IO}$ & Peard Bay & Ad. $q$ & 21 May 2005 & 13 Jul 2005 \\
\hline SI & Peard Bay & Ad. + P & 29 May 2005 & 25 Aug 2005 \\
\hline SJ & Peard Bay & Ad. + ? & 25 May 2005 & 09 Oct 2005 \\
\hline TT & Peard Bay & Ad. $\hat{\sigma}$ & 21 May 2005 & 27 Feb 2006 \\
\hline IB & Peard Bay & Ad. $\widehat{\sigma}$ & 17 May 2005 & 09 Jul 2006 \\
\hline SS & Peard Bay & Ad. + & 25 May 2005 & 05 Aug 2005 \\
\hline SE & Peard Bay & Juv. $\widehat{\sigma}$ & 25 May 2005 & 17 Jun 2005 \\
\hline $\mathrm{JJ}$ & Peard Bay & Ad. $\hat{\sigma}$ & 25 May 2005 & 21 Jun 2006 \\
\hline P1 & N. of Garry Is. & Ad. $\hat{\sigma}$ & 20 Mar 2006 & 21 Jun 2006 \\
\hline $\mathrm{P} 2$ & N. of Garry Is. & Ad. $\hat{\sigma}$ & 21 Mar 2006 & 23 Mar 2006 \\
\hline P3 & N. of Garry Is. & Ad. $\hat{\sigma}$ & 13 Apr 2006 & 29 Apr 2006 \\
\hline P4 & N. of Garry Is. & Ad. $\hat{\sigma}$ & 21 Mar 2006 & 25 Jun 2006 \\
\hline P5 & N. of Garry Is. & Ad. $q$ & 01 Apr 2006 & 25 Jun 2006 \\
\hline P6 & N. of Garry Is. & Ad. $q$ & 05 Jun 2006 & 09 Jun 2006 \\
\hline P7 & N. of Garry Is. & Ad. $q$ & 26 Mar 2006 & 17 Jun 2006 \\
\hline $\mathrm{AM}$ & Peard Bay & Ad. $\hat{o}$ & 28 Apr 2006 & 02 Nov 2006 \\
\hline BM & Peard Bay & Ad. $\hat{o}$ & 13 May 2006 & 07 Jun 2007 \\
\hline $\mathrm{AF}$ & Peard Bay & Ad. & 07 May 2006 & 26 Mar 2007 \\
\hline $\mathrm{CM}$ & Peard Bay & Ad. $\hat{\sigma}$ & 19 May 2006 & 17 Jan 2007 \\
\hline $\mathrm{BF}$ & Peard Bay & Ad. $q$ & 19 May 2006 & 05 Jun 2007 \\
\hline $\mathrm{JM}$ & Kotzebue Snd. & Ad. $\widehat{\sigma}$ & 19 May 2007 & 13 Jun 2007 \\
\hline JS & Kotzebue Snd. & Juv. $\sigma^{\lambda}$ & 25 May 2007 & 02 Dec 2007 \\
\hline
\end{tabular}

Seals were captured in the Chukchi Sea (Peard Bay and Kotzebue Sound) and in the Canadian Beaufort Sea $(50 \mathrm{~km}$ north of Garry Island). Ad. adult, $J u v$. juvenile 


\section{Results}

\section{Subnivean period}

The location of each of 58 ringed seals was determined $1-32(\bar{X}=12.8, \mathrm{SD}=7.02)$ times by tracking their radio signals when they rested on the ice during the subnivean period. The number of resting sites identified for each seal ranged from one to eight $(\bar{X}=3.4, \mathrm{SD}=1.53)$ and likely underestimated the actual number of sites used, as the seals' locations were not determined for every resting bout. The number of sites used increased with the number of times seals were located and reached an asymptote at 4.5 sites per seal.

Home range size was estimated for 55 of the seals tracked by VHF radio tags during the subnivean period in 1999-2003 (Fig. 2). The home ranges of adult males ranged from $<1$ to $13.9 \mathrm{~km}^{2}$ (median $=0.62 \mathrm{~km}^{2}$ ) while the home ranges of adult females ranged from $<1$ to $27.9 \mathrm{~km}^{2}$ (median $=0.65 \mathrm{~km}^{2}$ ). The differences in home range size were not statistically significant (Mann-Whitney $\left.U=346.0, n_{1}=27, n_{2}=28, P=0.596\right)$. Most (94\%) of the home ranges were less than $3 \mathrm{~km}^{2}$ during the subnivean period. Two of the larger home ranges included lairs $\geq 7 \mathrm{~km}$ apart between which seals moved repeatedly. In 2000, the home range of an adult female seal (OC00) included two lairs $8.6 \mathrm{~km}$ apart, and in 2001, an adult male (MK01) used two lairs separated by $7 \mathrm{~km}$. Nine seals were recaptured at breathing holes within the same breeding season 1-20 days after their initial capture. Each of those seals was captured within $1,300 \mathrm{~m}$ of their initial capture site.

Home ranges of different seals overlapped extensively (Fig. 2), and shared use of breathing holes was apparent from our trapping efforts. We captured two seals at the same breathing hole on nine occasions, and twice we captured three seals from the same breathing hole.

During the subnivean period, we also tracked the threedimensional movements under the ice of 2 adult males, 3 adult females, and 4 subadult seals for periods of 730 days. The under-ice, three-dimensional home ranges used by the seals (Fig. 3) ranged from 0.03 to $0.13 \mathrm{~km}^{3}$ $(\bar{X}=0.07, \mathrm{SD}=0.04)$ for subadults and adult males and from 0.10 to $0.17 \mathrm{~km}^{3}(\bar{X}=0.13, \mathrm{SD}=0.04)$ for adult females $(t=-1.980, d f=7, P=0.088)$. Volumes used by adult females (Fig. 3c, d) exceeded those used by adult males (Fig. 3a, b) and yearlings primarily in depth. Median dive depths were 89,106 , and $137 \mathrm{~m}$ for the adult females, 28 and $35 \mathrm{~m}$ for the adult males, $137 \mathrm{~m}$ for a subadult male, and 32, 27, and $64 \mathrm{~m}$ for the yearlings.

Overlapping under-ice home ranges were evident in the four instances where we compared the movements of pairs of seals. In 1990, a yearling female and an adult male were tracked by the same hydrophone array, and their under-ice ranges overlapped by $55.6 \%$. In 1991, the under-ice ranges of a subadult male and an adult male overlapped by $39.5 \%$ and those of two adult females overlapped by $45.7 \%$ (Fig. 3c, d). Overlap between a subadult male and an adult female in 1992 was $55.1 \%$. In each of these cases of overlap, the seals shared the use of one or more breathing holes.

From April to mid-May, the 58 seals tracked via VHF radios spent most of their time under the ice. They came out of the water only in subnivean lairs where they spent $16 \%$ (SD $=10 \%)$ of their time. The duration of subnivean resting bouts ranged from less than 1 to $42 \mathrm{~h}$ with a median of $6 \mathrm{~h}$ (Fig. 4). The interval between subnivean resting bouts ranged from 1 to $84 \mathrm{~h}$ with a median of $27 \mathrm{~h}$ (Fig. 5).

Most tagged seals exhibited a significant diel pattern in the proportion of time spent on the ice. Individuals varied in their preferred on-ice times, but subnivean lairs were occupied mostly between 1800 and 0600 hours local time (overall $\bar{X}=0110 \mathrm{~h}, \mathrm{SD}=6.10 \mathrm{~h}$ ) in April to mid-May. Similar diel haulout patterns were reported for ringed seals resting on the ice of a the Alaskan Beaufort Sea (Kelly and Quakenbush 1990) and in a fjord at Svalbard (Lydersen 1991; Carlens et al. 2006). The variance in times of day during which seals occupied lairs was large (Rao's $U=149.63,0.10>P>0.05, n=41$ ), and the probability of an individual seal being out of the water during any hour rarely exceeded 0.50 .

\section{Basking period}

As air temperature increased in May and June, the ringed seals abandoned their lairs either as the snow collapsed or by tunneling their way through the snow. After abandoning their lairs and before ice break-up, the radio-tagged ringed seals were visible when they basked on the ice. Most (56/ 58) basked on the ice within the same small home ranges they occupied during the subnivean period. In early June 2002, two seals basked 20 and $40 \mathrm{~km}$, respectively, beyond the ranges they occupied in the subnivean period.

The amount of time that radio-tagged seals spent out of the water increased $(\bar{X}=55 \%, \mathrm{SD}=22 \%)$ during the basking season. Twenty-six of 43 seals monitored before and after their first emergence from lairs occupied lairs one or more times after emergence. They spent an average of $3 \%(95 \%$ CL: $1-4 \%)$ of their time in lairs and an average of $37 \%$ (95\% CL: $32-41 \%$ ) of their time basking after the first emergence. The median duration of resting bouts on the ice (Fig. 4) increased to $9 \mathrm{~h}$ when the seals were basking while the median intervals between resting bouts (Fig. 5) decreased to $14 \mathrm{~h}$.

When basking in the spring, the tagged seals were on the ice primarily at mid-day $(\bar{X}=1646 \mathrm{~h}, \mathrm{SD}=1.46 \mathrm{~h})$. 
Fig. 2 Subnivean breathing holes and lairs located by trained dogs in 2003. The minimum convex polygons delineate the home ranges of 14 ringed seals based on on-ice resting sites. Similar home ranges were delineated in the same study site in 1999, 2000, 2001, and 2002

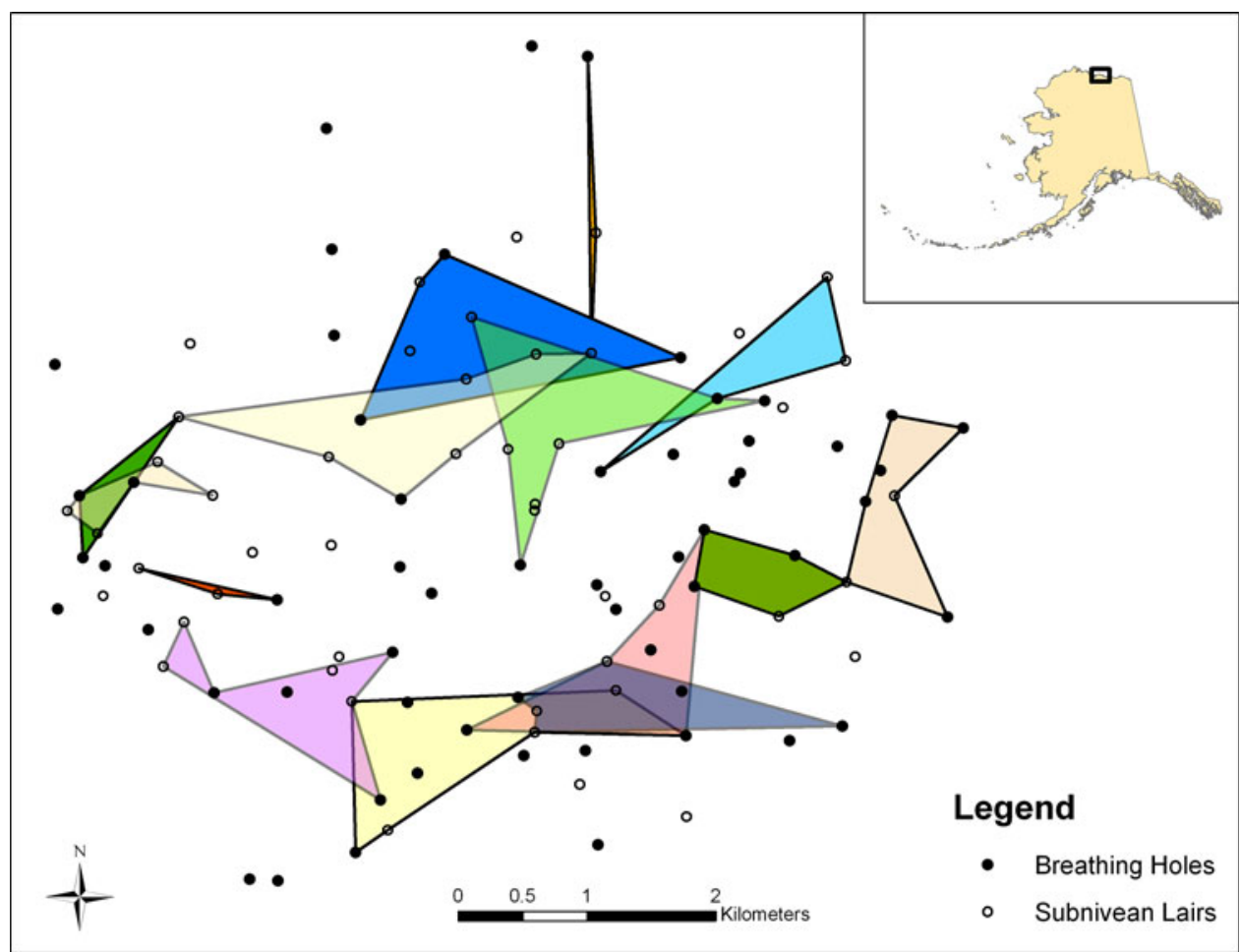

The shift from being out of the water mostly at night during the subnivean period (January-May) to being on the ice in late afternoon while basking (May-June) was highly significant $\left(U^{2}=1.591, P<0.001\right)$. The variance in time on the ice during the basking period was substantial (Rao's $U=286.78, P<0.01, n=59$ ), but the probability of a seal being out of the water during any hour often exceeded 0.50 , especially in the afternoon hours.

\section{Foraging period}

Three adult seals (two males and one female) tracked via VHF radios during the subnivean and basking periods were recaptured in the subsequent subnivean period, 371377 days after their initial capture. Their recapture sites were 746,1400 , and 2,000 $\mathrm{m}$ from the sites at which they were captured in the previous year. The home ranges of those three seals were similar in size, configuration, and number of lairs occupied in successive breeding seasons (Fig. 6). The unexpected interannual fidelity of those three seals to the same small home ranges in subsequent breeding seasons prompted us to track the annual movements of additional seals using satellite-linked transmitters.

We tracked 25 ringed seals carrying satellite-linked transmitters for periods ranging from 4 to 420 days. Nine seals tagged in Peard Bay were tracked from their tagging dates in May through January or beyond, well into the subsequent subnivean period. Two of the latter seals were tracked until the subsequent June (13 months after tagging) and one until the subsequent July (14 months after tagging). Four seals (3 tagged in Peard Bay and 1 in Kotzebue Sound) were followed for $>100$ and up to 193 days, thus providing movement information during the foraging period but minimally, if at all, during their subsequent subnivean period. We received signals from the seven seals tagged $50 \mathrm{~km}$ north of Garry Island (Canadian Beaufort Sea), four of those tagged at Peard Bay (Chukchi Sea), and one of those tagged in Kotzebue Sound (Chukchi Sea) for less than 100 days. Thus, for those 12 seals, we recorded movements during the subnivean and basking periods but not during the foraging period.

The nine seals tracked from one subnivean period to the next were consistent in their overall pattern of seasonal movements. During the late subnivean period and through the basking periods (May-June) in the year of capture, most seals remained within $50 \mathrm{~km}$ of their capture sites (Fig. 7). With the break-up of the shorefast ice in July, they began more extensive movements. From July through early December, they rested on moving ice as far as $900 \mathrm{~km}$ (in the case of one female) and over $1,700 \mathrm{~km}$ (in the case of one male) from their breeding sites in the shorefast ice. By the subsequent January, 8 of the 9 seals were again close $(3-54 \mathrm{~km})$ to the sites at which they had been captured during the previous breeding season. The ninth seal, an adult male, was not located from November (6 months after capture) until the following May when he was $83 \mathrm{~km}$ from the site at which he was captured 12 months earlier. Like the other seals tracked between successive subnivean 

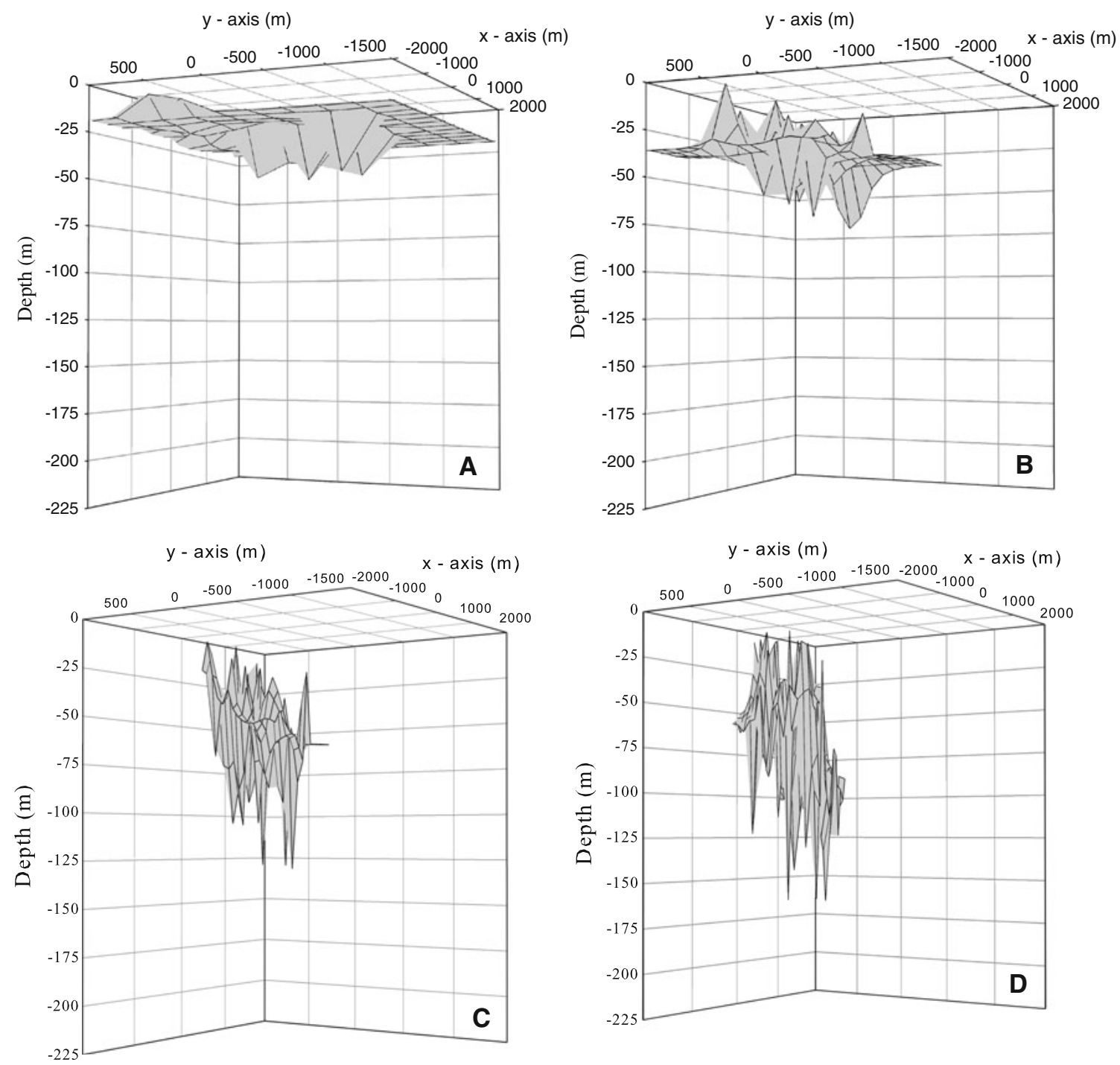

Fig. 3 Under-ice home ranges of breeding adult ringed seals tracked in Resolute Passage, NWT: a adult male tracked in 1990, b adult male tracked in 1991, c and d adult females tracked in 1991. The grid cells

periods, he made extensive movements during JulySeptember, returned to Peard Bay at freeze-up in October. In November, however, he made another excursion of almost $800 \mathrm{~km}$ to the west before returning to the Peard Bay region (Fig. 8). An adult female similarly ranged over $150 \mathrm{~km}$ in July from her breeding site in Peard Bay, returned to within $15 \mathrm{~km}$ of her breeding site in October, moved almost $900 \mathrm{~km}$ to the north in November, and was back within $3 \mathrm{~km}$ of her breeding site in January.

The ringed seals that we tracked by satellite rested exclusively on shorefast or pack ice; we recorded no episodes of ringed seals coming ashore. They came out onto ice in every month of the year, although the percentage time on the ice varied markedly throughout the year. In August through November, the satellite-tracked seals spent $10 \%$ or less of their time out of the water (Fig. 9). Time out

in $\mathbf{c}$ and $\mathbf{d}$ represent the same three-dimensional space, and the threedimensional home ranges of the females overlapped by $45.7 \%$

of the water increased slightly in December through March but still was less than $20 \%$. As with the seals tracked by VHF radio, those tracked by satellite-linked transmitters spent less than half of their time out of the water during the subnivean period. In June, however, when most seals were molting, they spent over $60 \%$ of their time on the ice. Time out of the water dropped to $30 \%$ in July as basking was completed and the foraging period commenced.

\section{Discussion}

The combination of acoustic, VHF radio, and satellitelinked tags allowed us examine movement patterns among ringed seals throughout the year. During the late summer and fall foraging period, ringed seals ranged over 
Fig. 4 Duration (hours) of haul-out bouts in subnivean lairs and out of lairs (basking)
Fig. 5 Interval (hours) between haul-out bouts in and out of subnivean lairs
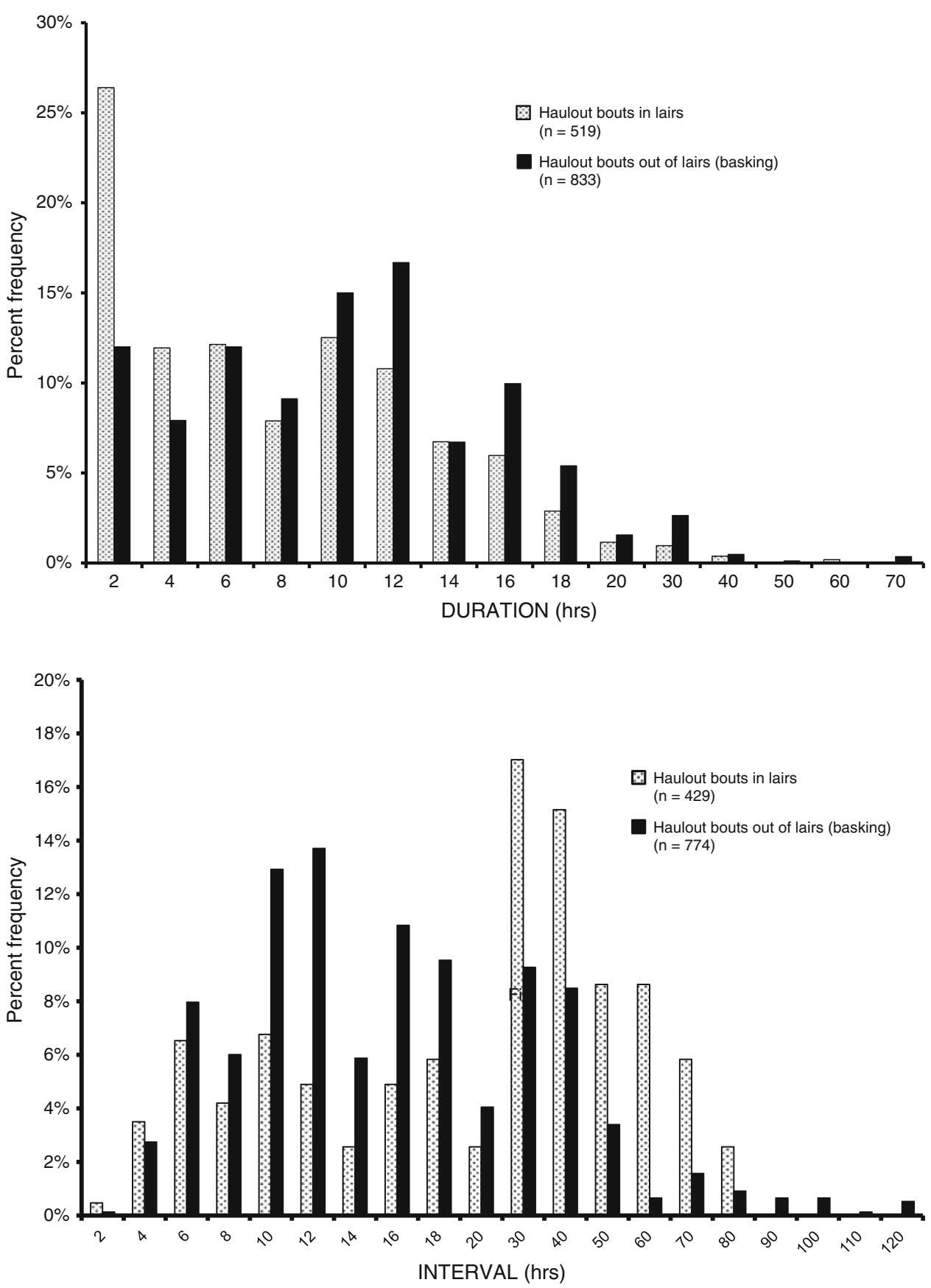

thousands of kilometers but continued to use sea ice as a resting platform. The percentage of time on the ice, however, exceeded $20 \%$ only in spring and early summer when ringed seals were giving birth, nursing young, and molting. Time out of the water averaged nearly $50 \%$ during the subnivean period and over $60 \%$ during the peak of the basking period consistent with previous observations during those periods (Kelly and Quakenbush 1990; Lydersen and Hammill 1993).

The holes that ringed seals maintain through sea ice provide access to air above and food below. Excavating subnivean lairs above some of those breathing holes permits ringed seals to rest and rear young in an environment that otherwise is too cold for the young; lairs also visually conceal them from predators (Taugbøl 1984; Smith et al. 1991). Adaptations for excavating ice and snow are primarily behavioral but also include stout claws on the foreflippers. Maintaining breathing holes through ice that can exceed $2 \mathrm{~m}$ in thickness restricts the areas in which the seals can forage for several months of the year. We found that ringed seals inhabiting shorefast ice in the Beaufort Sea occupied ranges averaging less than $2 \mathrm{~km}^{2}$ during 
Fig. 6 Minimum convex polygons delineating the home ranges of 3 ringed seals each tracked during two successive breeding seasons. IM was an adult male tracked in 2001 and 2002. SH was an adult female tracked in 2002 and 2003. WW was an adult male tracked in 2002 and 2003

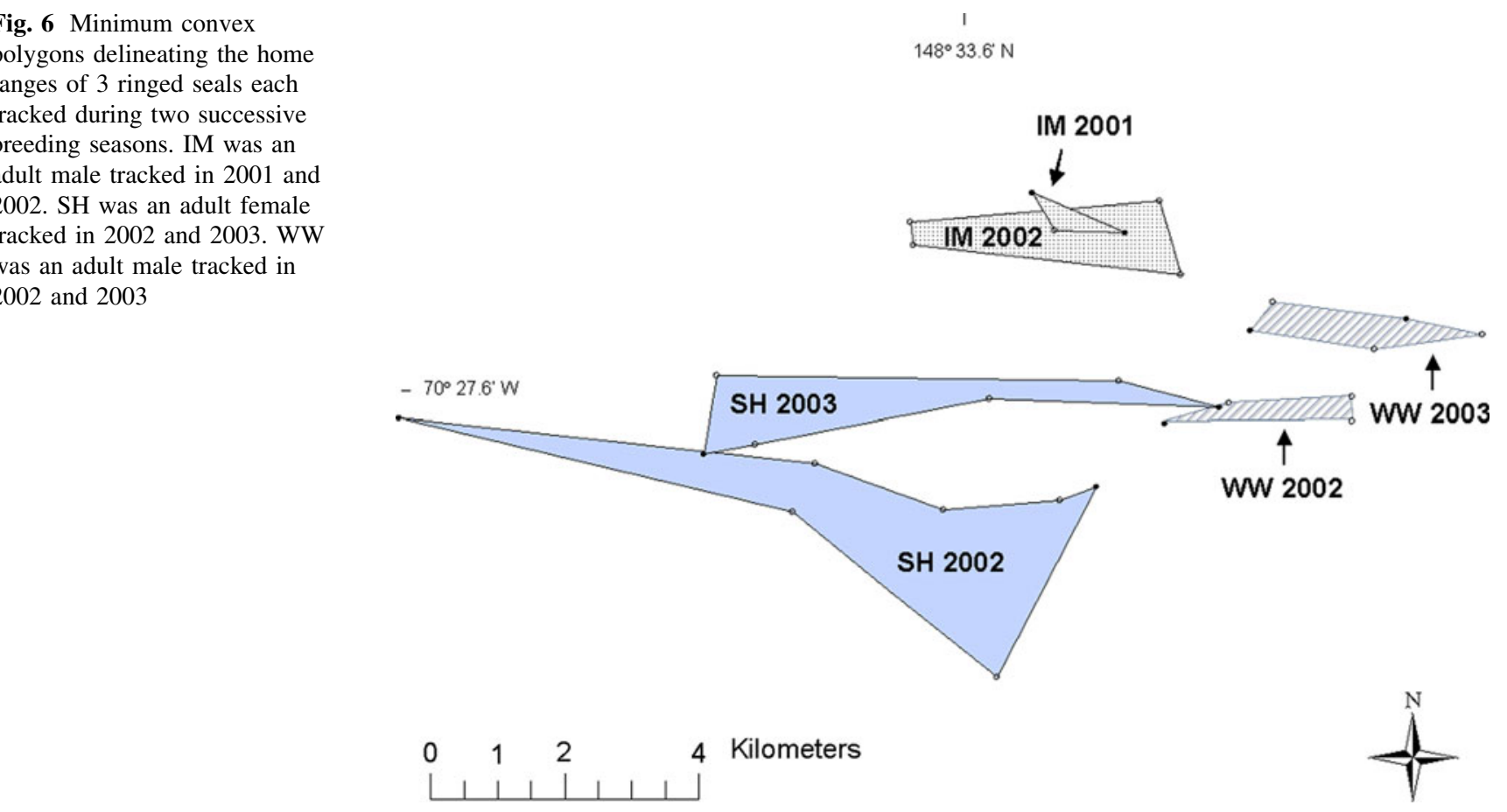

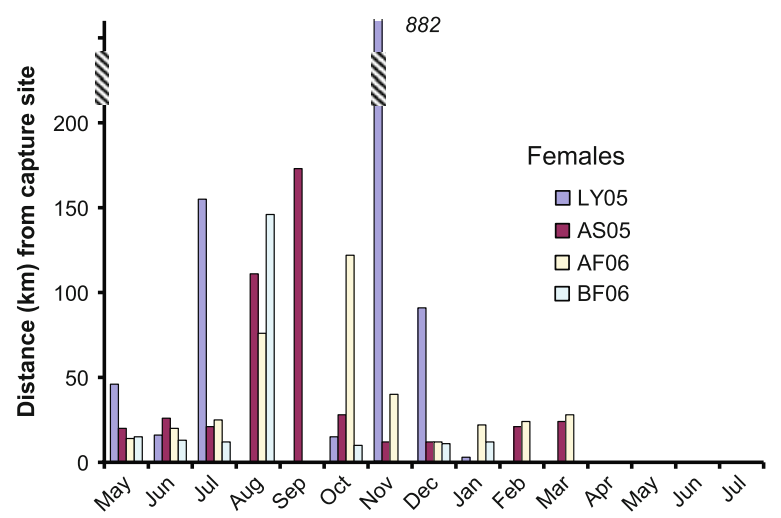

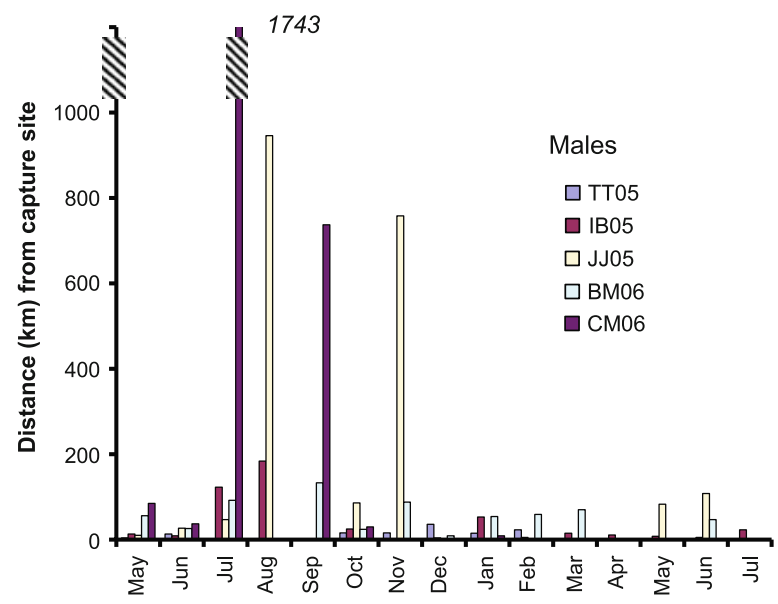

Fig. 7 Maximal distance from their capture site recorded each month for 9 satellite-tracked ringed seals. Note different scales in top and bottom panels and the break in $y$-axes on both
April, May, and early June, and the autumn movements of the satellite-tagged seals suggested that they probably are restricted to the same ranges beginning as early as freezeup in September or October. Thus, maintenance of breathing holes may restrict some ringed seals to foraging within tiny home ranges for as many as 10 months of the year.

During the subnivean period, under-ice movements did not substantially exceed the ranges determined by haul-out locations. For periods of 2-4 months in summer and fall, when ringed seals forage most intensively, however, they ranged over distances $>100 \mathrm{~km}$ and as far as $1,800 \mathrm{~km}$, in contrast to the more restricted movements in lakes and the Baltic Sea reported by Hyvärinen et al. (1995), Härkönen et al. (1998, 2008), Kunnasranta (2001), and Koskela et al. (2002). Our movement data likely underestimate the distances travelled during the foraging period, as our tags only reported the seals' locations when out of the water, and haul-out bouts were rare $(<10 \%$ of the time) during the foraging period.

When the shorefast ice forms again in the fall, the seals re-occupy nearly the identical home range used the previous winter and spring. Strong fidelity to breeding sites was observed in all 12 ringed seals ( 3 tracked via VHF radio transmitters and 9 via satellite-linked transmitters) that we tracked through subnivean periods in successive years. Smith and Hammill (1981) observed the same ringed seal resting on the ice of a Baffin Island fjord in two successive basking periods, and hunters from Norton Sound on the 
Fig. 8 Movements of an adult male ringed seal tracked from the breeding season of 2005 through the breeding season of 2006. He was tagged on shorefast ice of Peard Bay (near Barrow), Alaska in May 2005. As the ice retreated in summer, he ranged nearly $1,000 \mathrm{~km}$ east to the Canadian Beaufort Sea were he rested on pack ice in August 2005. At freeze-up in October 2005, he returned to Peard Bay. In November 2005, he traveled almost $800 \mathrm{~km}$ across the Chukchi Sea to the pack ice offshore of Siberia. He subsequently returned to the Peard Bay vicinity where he was last located on shorefast ice in June 2006
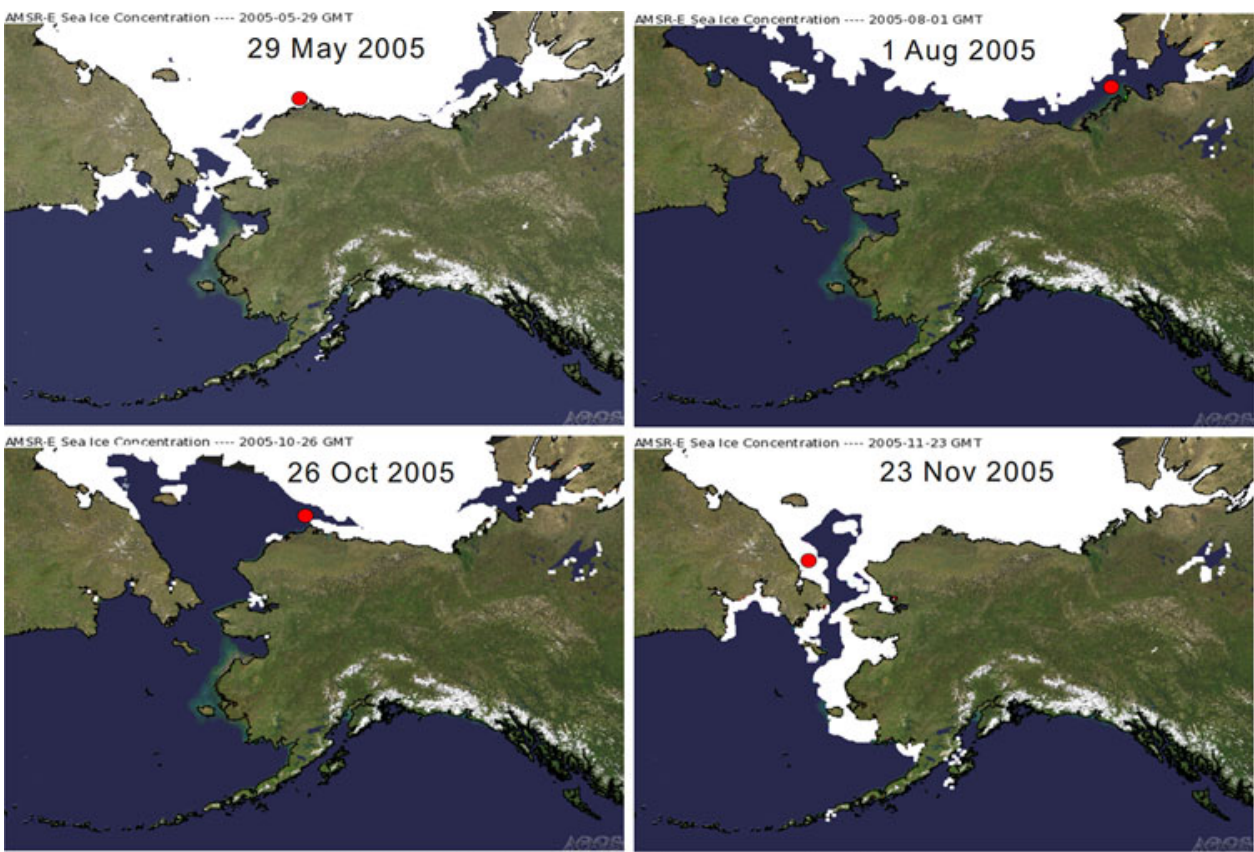

MSR-E, Sea Ice Concentration -.... 2006-06-21 chm

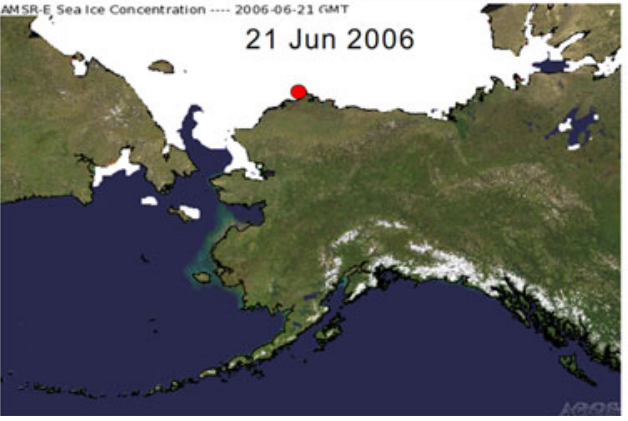

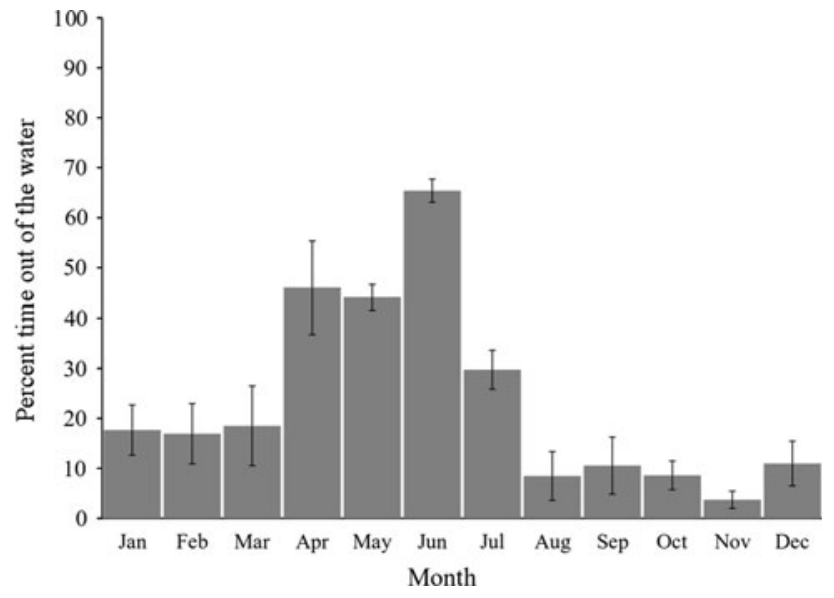

Fig. 9 Mean (and 95\% confidence limits) time out of the water calculated daily for each of 9 ringed seals tracked by satellite throughout the year

Bering Sea coast of Alaska reported recognizing a female ringed seal rearing a pup in the same location in 4 or 5 successive years (Huntington 2000). Krafft et al. (2007) reported that an unspecified number of "adult animals have been marked and then recaptured in the next year or after several years some few $100 \mathrm{~m}$ from where they were marked" in a fjord on Svalbard. Inter-annual fidelity to small ranges has implications for the foraging ecology, breeding biology, and population structure of ringed seals.

During lactation, breeding, and subsequent molting, phocid seals may be restricted in their movements for periods of a few weeks to 3 or 4 months (Costa 1991; Thompson et al. 1994; Boyd 1998; Schulz and Bowen 2005). The ringed seals that we tracked were confined to very small ranges for up to 10 months each year. The restriction to small home ranges probably is necessitated by maintenance of breathing holes and appears to limit the range over which ringed seals can forage for most of the year including the lactation period. At least through their first year, young ringed seals, by virtue of their size, are further restricted to feeding in shallow depths (Kelly and Wartzok 1996).

At 5-7 weeks, the lactation period in ringed seals is the longest among the Phocidae (Costa 1991; Hammill et al. 1991), and their small body size and prolonged confinement to small ranges apparently exceeds the duration of a 
sustainable fast. Elsewhere, we reported that the ringed seals we tracked under the ice in Resolute Passage made foraging dives throughout the breeding period (Kelly and Wartzok 1996; Simpkins et al. 2001). The small under-ice home ranges maintained during the subnivean period allow lactating females to frequently attend the pups in subnivean lairs. Frequent visits to the lairs likely increase the efficiency of energy transfer to the pup (Boyd 1998; Lydersen et al. 1992; Lydersen and Kovacs 1999) and minimize predation on pups by allowing their mothers to move them when predators attempt to excavate birth lairs (Taugbøl 1984; Smith et al. 1991). The small size of the under-ice ranges, however, limits access to prey, and ringed seals may compensate by using ranges that correspond to areas of high prey density. We suggest that interannual fidelity to the same under-ice home ranges reflects selection for occupying areas of high prey density. Foraging intensifies in the few months that ringed seals are not restricted to under-ice home ranges (Lowry et al. 1980; Ryg et al. 1990; Weslawski et al. 1994), and during the foraging period, ringed seals range hundreds to thousands of kilometers from their breeding sites. During the open-water period and early part of freeze-up when ringed seals forage most intensively, the seals that we tracked spent $90 \%$ or more of their time in the water. As ice cover thickened in January through March, the time spent in the water remained greater than $80 \%$. Only during the late subnivean period (when ringed seals whelp and nurse their young) and the basking period did the time in the water decline to less than $70 \%$.

The selection of breeding habitat by ringed seals has been considered in terms of ice and snow conditions (Chapskii 1940; McLaren 1958; Smith and Stirling 1975; Helle et al. 1984; Kelly 2001; Kunnasranta et al. 2001) and in terms of predation risk (Stirling 1977; Stirling and Archibald 1977; Smith 1976, 1980; Gjertz and Lydersen 1986; Lydersen and Smith 1989; Hammill and Smith 1991; Smith and Lydersen 1991; Smith et al. 1991; Furgal et al. 1996; Kelly 1996). Little attention has been directed, however, to investigating the possible influence of prey densities or availability on selection of breeding habitat (Nazarenko 1967; Siegstad et al. 1998; Holst et al. 2001).

The home ranges that we delineated near Prudhoe Bay during the subnivean period in 1999-2003 were all in shallow waters $(\leq 9 \mathrm{~m})$ where benthic or epontic organisms may be the only abundant prey. The dynamics of ringed seal prey and their influence on ringed seal home ranges are poorly known, but there is evidence of heterogeneity in benthic production in Arctic seas (Coyle and Highsmith 1994). Benthic and epontic feeding may be especially important when ringed seals inhabit shallow, nearshore waters (such as in our study site near Prudhoe Bay) during the subnivean period. There are patches of boulders in the near-shore waters of the Alaskan Beaufort Sea (Reimnitz and Ross 1979) that contain diverse and highly productive macroalgal and invertebrate assemblages (Dunton and Schonberg 2000). Several species of fish also are known to reside in these boulder communities, including the abundant Arctic sculpin Myoxocephalus scorpioides, whose biomass averages $24 \mathrm{~g} / \mathrm{m}^{2}$ (Dunton and Schonberg 2000). These rocky outcroppings are potentially rich and valuable sources of food for ringed seals. In spring when ringed seals are lactating, the underside of the ice also concentrates prey, including gammarid amphipods (Lewis and Milne 1977; Carey 1991), Arctic cod (Boreogadus saida) (Smith and Harwood 2001), and isopods (Harwood et al. 2007). Ringed seal feces examined opportunistically in our Resolute Bay and Prudhoe Bay study areas in May revealed the presence of amphipod and isopod exoskeletons.

Local concentrations of benthic prey are likely to be stable over time (Bernstein and Meador 1979; Schaffner and Boesch 1982; Carrasco 1997; Mincks et al. 2005; Shanks and Eckert 2005) and may favor interannual fidelity to breeding sites among ringed seals. Concentrations of prey on the underside of the ice appear to depend, in part, on the topography of that surface (Lewis and Milne 1977; Bradstreet 1982), which likely varies from year to year, and epontic prey concentrations may be less important in influencing the ringed seal's interannual fidelity to breeding sites. Our Resolute Passage study site was deeper $(225 \mathrm{~m})$ than our other sites, and the seals we tracked there foraged primarily in the mid-water column in the case of adults or near the under surface of the ice in the case of young animals (Kelly and Wartzok 1996; Simpkins et al. 2001). Site fidelity may offer less advantage in terms of knowledge of local resources in such sites.

Ringed seals in our study sites were still restricted to small under-ice ranges during lactation (April and May) and mating (May and June). Based on the distribution of lairs showing signs of parturition and of breathing holes and lairs smelling of rutting males, Smith and Stirling (1975) and Smith et al. (1991) suggested that males maintained large under-ice territories containing multiple female territories. An increase in vocalization rates in spring also has been interpreted as evidence of territoriality (Stirling et al. 1983), although Richardson et al. (1995) point out that "it has not been possible to associate specific behaviors and call types." Our tracking of ringed seals in the Beaufort and Chukchi seas indicated substantial overlap of areas used by adult females during the breeding season and that the above and under-ice ranges of females were larger than those of males. The male ranges were restricted in depth (Kelly and Wartzok 1996) as well as in horizontal extent. The restricted movements of males during the breeding season and the larger volumes used by 
adult females did not seem consistent with territorial defense. Our observations are suggestive of a male mating strategy that involves a form of mate guarding whereby they station themselves near the primary breathing hole of a post-parturient female until she is receptive. We observed substantial overlap in the under-ice ranges of all age classes and many instances of adult males sharing holes with adult females during the breeding season. We also detected the strong odor of rutting males at birth lairs, indicating that one or more males had visited a lair used by a female and her pup. We also observed-as have others (Smith et al. 1991; Krafft et al. 2007) — an increase in fresh wounds to the hindflippers of males with the onset of breeding, suggesting male-male aggression consistent with territoriality or mate guarding.

It may well be that patterns of social interaction vary over the wide range of ringed seals. For example, in Lake Ladoga, Russia, multiple non-breeding ringed seals occupy the same lair (Kunnasranta et al. 2001). In Lake Baikal, however, home ranges (measured at the surface) of the closely related Baikal seal (Phoca sibirica) did not overlap, and seals are reported to avoid each other during the basking period (Martinkova et al. 2001). In some years, seals in the Bothnian Bay, Baltic Sea showed an even distribution consistent with territorial spacing (Härkönen et al. 1998). Our sample of ringed seals in shorefast ice in Alaska and Canada may not be representative of seals occupying pack ice or even shorefast ice in other parts of the Arctic.

While the concentration of estrus females in space and time has led to high levels of polygyny in many pinniped species (Bartholomew 1970; Emlen and Oring 1977), aquatic, under-ice breeding among ringed seals appears to reduce the potential for polygyny (Bertram 1940; Stirling 1975, 1983). We suggest that the necessity of maintaining breathing holes constrains ringed seals to low levels of polygyny. It might also be that ringed seal males practice mixed strategies as has been suggested for hooded seals (Kovacs 1990).

Our tracking records provide strong evidence of interannual fidelity to breeding sites among Arctic ringed seals as do observations of ringed seals in Lake Saimaa (Helle et al. 1984; Sipilä 1990). Site fidelity has been documented in several other phocid species including harbor seals (Phoca vitulina), grey seals (Halichoerus grypus), southern elephant seals (Mirounga leonina), and Weddell seals (Leptonychotes weddellii) (Allen et al. 1995: Goodman 1998; Pomeroy et al. 2000; Härkönen and Harding 2001; Karlsson 2003; Fabiani et al. 2006; Cameron et al. 2007; Poland et al. 2008). Fidelity to breeding sites suggests that gene flow may be restricted for one or both sexes. In our study, both male and female ringed seals showed fidelity to breeding sites; our data are limited, however, to observations of 12 individuals in two successive breeding seasons, and whether the observed site fidelity reflects natal philopatry remains to be determined. We have initiated an investigation of molecular markers from around the Arctic to further investigate population structuring among ringed seals.

We expect the importance of understanding the population structure of ice-associated seals to increase as diminishing sea ice habitat intensifies management concerns. In recent centuries, Northern Hemisphere sea ice provided over $16,000,000 \mathrm{~km}^{2}$ of substrate on which iceassociated seals rested, gave birth, nursed their young, and completed an annual molt. In recent decades, however, that substrate has been decreasing (Overland and Wang 2007; Serreze et al. 2007; Comiso et al. 2008), and summer ice may disappear completely within the next 50 years. That reduction in sea ice is expected to negatively impact ringed seal populations (Tynan and DeMaster 1997; Kelly 2001; Smith and Harwood 2001; Stirling and Smith 2004; Ferguson et al. 2005; Freitas et al. 2008b; Laidre et al. 2008; Schmölcke 2008; Cooper et al. 2009).

Changes in community structure associated with diminished sea ice likely will affect food sources for ringed seals. For example, shorter periods of ice cover will decrease the supply of ice algae, and increase the supply of phytoplankton reaching benthic shelf communities (Overland and Stabeno 2004; Grebmeier et al. 2006). Arctic cod rely on sea ice as cover from their many predators (Bradstreet and Cross 1982; Poltermann 2001), and diminished ice cover may threaten the viability of this important prey of ringed seals.

At the same time, increasingly early snow melts will further threaten ringed seal recruitment (Kelly 2001; Meier et al. 2004; Stirling and Smith 2004). The vulnerability of ringed seals to losses of snow and ice cover will be determined, in large measure, by population structure. If, as suggested by the observed fidelity to breeding sites, they are comprised of many locally adapted demes, the potential for local extinction is much higher than if there is extensive gene flow.

Acknowledgments This project was supported by the Office of Naval Research, the Coastal Marine Institute (Minerals Management Service and the University of Alaska Fairbanks), the North Pacific Research Board (Publication number 241), the National Marine Mammal Laboratory (National Marine Fisheries Service), the Natural Resources Fund (University of Alaska), and the National Science Foundation while the first author was working in the Office of Polar Programs. The Polar Continental Shelf Project (Canada); the Hunters and Trappers Association of Resolute Bay, NorthwestTerritories, Canada; BP Alaska; ConocoPhillips; the Department of Wildlife Management, North Slope Borough, Alaska; the Nanuuq Commission; the Ice Seal Committee; the Native Village of Kotzebue; the Department of Fisheries and Oceans (Canada); Ida and Nathaniel Olemaun Jr., Ross Schaeffer Sr., and Alex Whiting provided expertise and logistic support. Seal tracking was labor intensive, and we were 
assisted in the field and laboratory by over 50 hard-working and coldtolerant individuals including P. Amariluk, J. Bengtson, H. Cleator, M. Cronin, R. Ettagiak, R. Flinn, L. Harwood, S. Innes, J. Jones, C. Kelly, J. London, T. Manik, D. MacDonald, R. Memorana, J. Nielsen, L. Quakenbush, R. Schaeffer, M. Simpkins, T. Smith; S. Sell, R. Sneider, B. Taras, A. Whiting, and 12 students from the University of Alaska Southeast's Research Experiences for Undergraduates program. J. London and M. Cameron assisted with data reduction and graphics. A draft of this manuscript was improved by comments from Erin Moreland and Elizabeth Mathews. This research was conducted under the terms of Scientific Research Permits No. 350-1434 and 7821694-00 issued by the Office of Protected Resources, National Marine Fisheries Service, United States and Scientific License numbers SLE04/05-328 and SLE-05/06-322 issued by the Department of Fisheries and Oceans (DFO), Canada. Animal Care Use Protocols were issued by the University of Alaska Fairbanks (Assurance 08-11) and the DFO (UFWI-ACC-2004-2005-001U).

Open Access This article is distributed under the terms of the Creative Commons Attribution Noncommercial License which permits any noncommercial use, distribution, and reproduction in any medium, provided the original author(s) and source are credited.

\section{References}

Allen PJ, Amos W, Pomeroy PP, Twiss SD (1995) Microsatellite variation in grey seals (Halichoerus grypus) shows evidence of genetic differentiation between two British breeding colonies. Mol Ecol 4:653-662

Barber CB, Dobkin DP, Huhdanpaa HT (1996) The Quickhull algorithm for convex hulls. ACM Trans Math Softw 22:469-483

Bartholomew GA (1970) A model for the evolution of pinniped polygyny. Evolution 24:546-559

Batschelet E (1981) Circular statistics in biology. Academic Press, London

Bengtson JL, Hiruki-Raring LM, Simpkins MA, Boveng PL (2005) Ringed and bearded seal densities in the eastern Chukchi Sea, 1999-2000. Polar Biol 28:833-845

Bernstein BB, Meador JP (1979) Temporal persistence of biological patch structure in abyssal benthic community. Mar Biol $51: 179-183$

Bertram GLC (1940) The biology of the Weddell and crabeater seals: with a study of the comparative behaviour of the pinnipedia. $\mathrm{Br}$ Mus Nat Hist Sci Rep 1:39

Boas F (1888) The Central Eskimo. Annu Rep Bur Am Ethnol 6:339669 (Smithsonian Institution, Washington DC)

Born EW, Teilmann J, Acquarone M, Riget FF (2004) Habitat use of ringed seals (Phoca hispida) in the North Water Area (North Baffin Bay). Arctic 57:129-142

Boyd IL (1998) Time and energy constraints in pinniped lactation. Am Nat 152:717-728

Bradstreet MSW (1982) Occurrence, habitat use, and behavior of seabirds, marine mammals, and Arctic cod at the Pond Inlet ice edge. Arctic 35:28-40

Bradstreet MSW, Cross WE (1982) Trophic relationships at high arctic ice edges. Arctic 35:1-12

Burns JJ (1970) Remarks on the distribution and natural history of pagophilic pinnipeds in the Bering and Chukchi Seas. J Mamm 51:445-454

Cameron MF, Siniff DB, Proffitt KM, Garrott RA (2007) Site fidelity of Weddell seals: the effects of sex and age. Antarct Sci 19:149-155

Carey AG Jr (1991) Ecology of North American arctic continental shelf benthos: a review. Cont Shelf Res 11:865-883
Carlens HC, Lydersen C, Krafft BA, Kovacs KM (2006) Spring haulout behavior of ringed seals (Pusa hispida) in Kongsfjorden, Svalbard. Mar Mamm Sci 22:379-393

Carrasco FD (1997) Sublittoral macrobenthic fauna off Punta Coloso, Antofagasta, northern Chile: high persistence of the polychaete assemblage. Bull Mar Sci 60:443-459

Chapskii KK (1940) The ringed seal of western seas of the Soviet Arctic (The morphological characteristic, biology and hunting production). Tr Vses Arkt Inst (Leningr) 145:1-72 (Transl from Russ by Fish Res Board Can, 1971, Transl Ser 1665)

Comiso JC, Parkinson CL, Gersten R, Stock L (2008) Accelerated decline in the Arctic Sea ice cover. Geophys Res Lett 35:L01703

Cooper MS, Budge S, Springer A, Sheffield G (2009) Resource partitioning by sympatric pagophilic seals in Alaska: monitoring effects of climate variation with fatty acids. Polar Biol 32:11371145

Costa DP (1991) Reproductive and foraging energetics of pinnipeds: implications for life history patterns. In: Renouf D (ed) The behaviour of pinnipeds. Chapman \& Hall, London, pp 300-344

Cox SL, Spiess A (1980) Dorset settlement and subsistence in northern Labrador. Arctic 33:659-669

Coyle KO, Highsmith RC (1994) Benthic amphipod community in the northern Bering Sea: analysis of potential structuring mechanisms. Mar Ecol Prog Ser 107:233-244

Davis CS (2004) Phylogenetic relationships of the Phocidae and population genetics of ice-breeding seals. Dissertation, University of Alberta

Davis CS, Stirling I, Strobeck C, Coltman DW (2008) Population structure of ice-breeding seals. Mol Biol 17:3078-3094

Doncaster CP (1990) Non-parametric estimates of interaction from radio-tracking data. J Theor Biol 143:431-443

Dunton KH, Schonberg SV (2000) The benthic faunal assemblage of the Boulder Patch kelp community. In: Truett JC, Johnson SR (eds) The natural history of an arctic oil field. Academic Press, San Diego, pp 372-400

Emlen ST, Oring LW (1977) Ecology, sexual selection, and the evolution of mating systems. Science 197:215-223

Fabiani A, Galimberti F, Sanvito S, Hoelzel R (2006) Relatedness and site fidelity at the southern elephant seal, Mirounga leonina, breeding colony in the Falkland Islands. Anim Behav 72:617626

Feltz ET, Fay FH (1966) Thermal requirements in vitro of epidermal cells from seals. Cryobiology 3:261-264

Ferguson SH, Stirling I, Mcloughlin P (2005) Climate change and ringed seal (Phoca hispida) recruitment in Western Hudson Bay. Mar Mamm Sci 21:121-135

Finley KJ, Miller GW, Davis RA, Koski WR (1983) A distinctive large breeding population of ringed seals (Phoca hispida) inhabiting the Baffin Bay pack ice. Arctic 36:162-173

Freitas C, Kovacs KM, Ims RA, Fedak MA, Lydersen C (2008a) Ringed seal post-moulting movements tactics and habitat selection. Oecologia 155:193-204

Freitas C, Kovacs KM, Ims RA, Fedak MA, Lydersen C (2008b) Predicting habitat use by ringed seals (Phoca hispida) in a warming Arctic. Ecol Model 217:19-32

Furgal CM, Innes S, Kovacs KM (1996) Characteristics of ringed seal, Phoca hispida, subnivean structures and breeding habitat and their effects on predation. Can J Zool 74:858-874

Gjertz I, Lydersen C (1986) Polar bear predation on ringed seals in the fast-ice of Hornsund, Svalbard. Polar Res 4:65-68

Goodman SJ (1998) Patterns of extensive genetic differentiation and variation among European harbor seals (Phoca vitulina vitulina) revealed using microsatellite DNA polymorphisms. Mol Biol Evol 15:104-118

Grebmeier JM, Overland JE, Moore SE, Farley EV, Carmack EC, Cooper LW, Frey KE, Helle JH, McLaughlin FA, McNutt SL 
(2006) A major ecosystem shift in the northern Bering Sea. Science 311:1461-1464

Hall CF (1866) Arctic researches and life among the Esquimaux: being the narrative of an expedition in search of Sir John Franklin, in the years 1860, 1861, and 1862. Harper Brothers Publishers, New York

Hammill MO, Smith TG (1991) The role of predation in the ecology of the ringed seal in Barrow Strait, Northwest-Territories, Canada. Mar Mamm Sci 7:123-135

Hammill MO, Lydersen C, Ryg M, Smith TG (1991) Lactation in the ringed seal (Phoca hispida). Can J Fish Aquat Sci 48:2471-2476

Härkönen T, Harding KC (2001) Spatial structure of harbour seal populations and the implications thereof. Can J Zool 79:21152127

Härkonen T, Jüssi M, Jüssi I, Verevkin M, Dmitrieva L, Helle E, Sagitov R, Harding KC (2008) Seasonal activity budget of adult Baltic ringed seals. PLoS ONE 3:e2006

Härkönen T, Stenman O, Jüssi M, Jüssi I, Sagitov R, Verevkin M (1998) Population size and distribution of the Baltic ringed seal (Phoca hispida botnica). In: Heide-Jorgensen MP, Lydersen C (eds) Ringed seals in the North Atlantic. The North Atlantic Marine Mammal Commission, Troms $\varnothing$, pp 167-180

Harwood LA, Smith TG, Melling H (2007) Assessing the potential effects of near shore hydrocarbon exploration on ringed seals in the Beaufort Sea Region 2003-2006. Environmental Studies Research Funds 162

Heide-Jørgensen MP, Stewart BS, Leatherwood S (1992) Satellite tracking of ringed seals Phoca hispida off northwest Greenland. Ecography 15:56-61

Helle E, Hyvärinen H, Sipilä T (1984) Breeding habitat and lair structure of the Saimaa ringed seal Phoca hispida saimensis Nordq. in Finland. Acta Zool Fenn 172:125-127

Holst M, Stirling I, Hobson KA (2001) Diet of ringed seals (Phoca hispida) on the east and west sides of the North Water Polynya, northern Baffin Bay. Mar Mamm Sci 17:888-908

Huntington HP (2000) Traditional ecological knowledge of seals in Norton Bay, Alaska. Report to the Elim-Shaktoolik-Koyuk Marine Mammal Commission and the National Marine Fisheries Service

Hyvärinen H, Hämäläinen E, Kunnasranta M (1995) Diving behavior of the Saimaa ringed seal (Phoca hispida saimensis Nordq.). Mar Mamm Sci 11:324-334

Kapel FO, Christiansen J, Heide-Jørgensen MP, Härkönen T, Born EW, Knutsen L, Riget F, Teilmann J (1998) Netting and conventional tagging used to study movements of ringed seals (Phoca hispida) in Greenland. In: Heide-Jorgensen MP, Lydersen $\mathrm{C}$ (eds) Ringed seals in the North Atlantic. The North Atlantic Marine Mammal Commission, Troms $\varnothing$, pp 211-228

Karlsson O (2003) Population structure, movements and site fidelity of grey seals in the Baltic. Thesis, Stockholm University, Sweden

Kelly BP (1988) Ringed seal, Phoca hispida. In: Lentfer JW (ed) Selected marine mammals of Alaska: species accounts with research and management recommendations. Marine Mammal Commission, Washington, DC, pp 59-75

Kelly BP (1996) Live capture of ringed seals in ice-covered waters. J Wildl Manag 60:678-684

Kelly BP (2001) Climate change and ice breeding pinnipeds. In: Walther G-R, Burga CA, Edwards PJ (eds) "Fingerprints" of climate change: adapted behaviour and shifting species' ranges. Kluwer Academic/Plenum Publishers, New York/London, pp 43-55

Kelly BP, Quakenbush LT (1987) Trained dogs and wild seals. Whalewatcher J Am Cetacean Soc 21:8-11

Kelly BP, Quakenbush LT (1990) Spatiotemporal use of lairs by ringed seals (Phoca hispida). Can J Zool 68:2503-2512
Kelly BP, Wartzok D (1996) Ringed seal diving behavior in the breeding season. Can J Zool 74:1547-1555

King JE (1983) Seals of the world, 2nd edn. Comstock Publ Assoc, Ithaca, NY

Koskela JT, Kunnasranta M, Hämäläinen E, Hyvärinen H (2002) Movements and use of haul-out sites of radio-tagged Saimaa ringed seal (Phoca hispida saimensis Nordq.) during the openwater season. Annal Zool Fenn 39:59-67

Kovacs KM (1990) Mating strategies in male hooded seals (Cystophora cristata)? Can J Zool 68:2499-2502

Krafft BA, Kovacs KM, Lydersen C (2007) Distribution of sex and age groups of ringed seals Pusa hispida in the fast-ice breeding habitat of Kongsfjorden, Svalbard. Mar Ecol Prog Ser 335:199-206

Kunnasranta M (2001) Behavioural biology of two ringed seal (Phoca hispida) subspecies in the large European lakes Saimaa and Ladoga. Dissertation, University of Joensuu, Finland

Kunnasranta M, Hyvärinen H, Sipilä T, Medvedev N (2001) Breeding habitat and lair structure of the ringed seal (Phoca hispida ladogensis) in northern Lake Ladoga in Russia. Polar Biol 24:171-174

Laidre KL, Stirling I, Lowry LF, Wiig $\varnothing$, Heide-Jørgensen MP, Ferguson SH (2008) Quantifying the sensitivity of Arctic marine mammals to climate-induced habitat change. Ecol Appl 18(2 Supplement):S97-S125

Lewis EL, Milne AW (1977) Underwater sea ice formations. In: Dunbar MJ (ed) Polar seas, Arct Inst N Am. Calgary, Alberta, pp 239-244

Lowry LF, Frost KJ, Burns JJ (1980) Variability in the diet of ringed seals, Phoca hispida, in Alaska. Can J Fish Aquat Sci 37:22542261

Lydersen C (1991) Monitoring ringed seal (Phoca hispida) activity by means of acoustic telemetry. Can J Zool 69:1178-1182

Lydersen C, Hammill MO (1993) Diving in ringed seal (Phoca hispida) pups during the nursing period. Can J Zool 71:991-996

Lydersen C, Kovacs KM (1999) Behaviour and energetics of icebreeding, North Atlantic phocid seals during the lactation period. Mar Ecol Prog Ser 187:265-281

Lydersen C, Smith TG (1989) Avian predation on ringed seal Phoca hispida pups. Polar Biol 9:489-490

Lydersen C, Hammill MO, Ryg M (1992) Water flux and mass gain during lactation in free-living ringed seal (Phoca hispida) pups. J Zool Lond 228:361-369

Martinkova N, Zahradnikova A, Budeev JA, Vrsansky P (2001) Surface home ranges of the Baikal seal (Phoca sibirica) during the solid ice-cover period. Biol Bratislava 56:219-224

McLaren IA (1958) The biology of the ringed seal (Phoca hispida Schreber) in the eastern Canadian arctic. Fish Res Board Can MS Rep Ser (Biol) 653:1-97

Meier HEM, Döscher R, Halkka A (2004) Simulated distributions of Baltic Sea-ice in warming climate and consequences for the winter habitat of the Baltic ringed seal. Ambio 33:249-256

Mincks SL, Smith CR, DeMaster DJ (2005) Persistence of labile organic matter and microbial biomass in Antarctic shelf sediments: evidence of a sediment 'food bank'. Mar Ecol Prog Ser 300:3-19

Mohr CO (1947) Table of equivalent populations of North American small mammals. Am Field Nat 37:223-249

Nazarenko YI (1967) Feeding of the ringed seal of the European north of the USSR. Can Transl Fish Aquat Sci 21:81-85

Overland JE, Stabeno PJ (2004) Is the climate of the Bering Sea warming and affecting the ecosystem? EOS 85:309-312

Overland JE, Wang MY (2007) Future regional Arctic sea ice declines. Geophys Res Lett 34:L17705

Poland VF, Pomeroy PP, Twiss SD, Graves JA (2008) Fine-scale study finds limited evidence of kin clustering in a gray seal colony. Mar Mamm Sci 24:371-387 
Poltermann M (2001) Arctic sea ice as feeding ground for amphipods-food sources and strategies. Polar Biol 24:89-96

Pomeroy PP, Twiss SD, Redman P (2000) Philopatry, site fidelity and local kin associations within grey seal breeding colonies. Ethology 106:899-919

Reeves RR (1998) Distribution, abundance and biology of ringed seals (Phoca hispida): an overview. In: Heide-Jorgensen MP, Lydersen C (eds) Ringed seals in the North Atlantic. The North Atlantic Marine Mammal Commission, Troms $\varnothing$, pp 9-45

Reimnitz E, Ross CR (1979) Lag deposits of boulders in Stefansson Sound, Beaufort Sea, Alaska. US Geol Surv Open File Rep 79-1205. Available at US Geol Surv, Menlo Park, California 94025

Richardson WJ, Greene CR Jr, Malme CI, Thomson DH (1995) Marine mammals and noise. Academic Press Inc, San Diego

Ridoux V, Hall AJ, Steingrimsson G, Olafsson G (1998) An inadvertent homing experiment with a young ringed seal, Phoca hispida. Mar Mamm Sci 14:883-888

Rurik L, Macdonald DW (2003) Home range and habitat use of the kit fox (Vulpes macrotis) in a prairie dog (Cynomys ludovicianus) complex. J Zool Lond 259:1-5

Ryg M, Smith TG, Øritsland NA (1990) Seasonal changes in body mass and body composition of ringed seals (Phoca hispida) on Svalbard. Can J Zool 68:470-475

Sabo G III, Jacobs JD (1980) Aspects of Thule culture adaptations in southern Baffin Island. Arctic 33:487-504

Schaffner LC, Boesch DF (1982) Spatial and temporal resource use by dominant benthic Amphipoda (Ampeliscidae and Corophoiidae) on the Middle Atlantic Bight Outer Continental Shelf. Mar Ecol Prog Ser 9:231-243

Scheffer VB (1958) Seals, sea lions and walruses. A review of the pinnipedia. Stanford University Press, Stanford

Schmölcke U (2008) Holocene environmental changes and the seal (Phocidae) fauna of the Baltic Sea: coming, going and staying. Mamm Rev 38:231-246

Schulz TM, Bowen WD (2005) The evolution of lactation strategies in pinnipeds: a phylogenetic analysis. Ecol Monogr 75:159-177

Serreze MC, Holland HM, Stroeve J (2007) Perspectives on the Arctic's shrinking sea-ice cover. Science 315:1533-1536

Shanks AL, Eckert GL (2005) Population persistence of California current fishes and benthic crustaceans: a marine drift paradox. Ecol Monogr 75:505-524

Siegstad H, Neve PB, Heide-Jørgensen MP, Härkönen T (1998) Diet of the ringed seal (Phoca hispida) in Greenland. In: HeideJorgensen MP, Lydersen C (eds) Ringed seals in the North Atlantic. The North Atlantic Marine Mammal Commission, Troms $\varnothing$, pp 229-241

Simpkins MA, Kelly BP, Wartzok D (2001) Three-dimensional analysis of search behaviour by ringed seals. Anim Behav 62:67-72

Sipilä T (1990) Lair structure and breeding habitat of the Saimaa ringed seal (Phoca hispida saimensis Nordq.) in Finland. Finn Game Res 47:11-20

Smith TG (1973) Population dynamics of the ringed seal in the Canadian eastern Arctic. Bull Fish Res Bd Can 181:1-55

Smith TG (1976) Predation of ringed seal pups (Phoca hispida) by the arctic fox (Alopex lagopus). Can J Zool 54:1610-1616

Smith TG (1980) Polar bear predation of ringed and bearded seals in the land-fast ice habitat. Can J Zool 58:2201-2209
Smith TG, Hammill MO (1981) Ecology of the ringed seal, Phoca hispida, in its fast ice breeding habitat. Can J Zool 59:966-981

Smith TG, Harwood LA (2001) Observations of neonate ringed seals, Phoca hispida, after early break-up of the sea ice in Prince Albert Sound, Northwest Territories, Canada, spring 1998. Polar Biol 24:215-219

Smith TG, Lydersen C (1991) Availability of suitable land-fast ice and predation as factors limiting ringed seal populations, Phoca hispida, in Svalbard. Polar Res 10:585-594

Smith TG, Stirling I (1975) The breeding habitat of the ringed seal (Phoca hispida); the birth lair and associated structures. Can J Zool 53:1297-1305

Smith TG, Hammill MO, Taugbøl G (1991) A review of the developmental, behavioural and physiological adaptations of the ringed seal, Phoca hispida, to life in the Arctic winter. Arctic 44:124-131

Stirling I (1975) Factors affecting the evolution of social behaviour in the pinnipedia. J Int Counc Explor Sea 169:205-212

Stirling I (1977) Adaptations of Weddell and ringed seals to exploit the polar fast ice habitat in the absence or presence of surface predators. In: Llano GA (ed) Adaptations within antarctic ecosystems. Proceedings of the 3rd symposium on antarctic biology. Gulf Publishing Co, Houston, pp 741-748

Stirling I (1983) The evolution of mating systems in pinnipeds. In: Eisenberg JF (ed) Advances in the study of mammalian behavior. Spec Publ Am Soc Mamm 7, Shippensburg, pp 489-527

Stirling I, Archibald WR (1977) Aspects of predation of seals by polar bears. J Fish Res Board Can 34:1126-1129

Stirling I, Smith TG (2004) Implications of warm temperatures and an unusual rain event for the survival of ringed seals on the coast of Southeastern Baffin Island. Arctic 57:59-67

Stirling I, Calvert W, Cleator H (1983) Underwater vocalizations as a tool for studying the distribution and relative abundance of wintering pinnipeds in the high arctic. Arctic 36:262-274

Taugbøl G (1984) Ringed seal thermoregulation, energy balance and development in early life, a study on Pusa hispida in Kongsfd., Svalbard. Thesis, Zoofysiologisk Institutt, University of Oslo, Norway (Can Transl Fish Aquat Sci No 5090)

Taylor WE (1968) An archaeological overview of Eskimo economy. In: Valentine VF, Vallee FG (eds) Eskimo of the Canadian Arctic. McClelland and Steward Ltd., Toronto, pp 3-17

Teilmann J, Born EW, Acquarone M (1999) Behaviour of ringed seals tagged with satellite transmitters in the North Water polynya during fast-ice formation. Can J Zool 77:1934-1946

Thompson PM, Miller D, Cooper R, Hammond PS (1994) Changes in the distribution and activity of female harbour seals during the breeding season: implications for their lactation strategy and mating patterns. Anim Ecol 63:24-30

Tynan CT, DeMaster DP (1997) Observations and predictions of arctic climatic change: potential effects on marine mammals. Arctic 50:308-322

Wartzok D, Sayegh S, Stone H, Barchak J, Barnes W (1992) Acoustic tracking system for monitoring under-ice movements of polar seals. J Acoust Soc Am 92:682-687

Weslawski JM, Ryg M, Smith TG, Øritsland NA (1994) Diet of ringed seals (Phoca hispida) in a fjord of West Svalbard. Arctic 47:109-114

Wiig Ø, Derocher AE, Belikov SE (1999) Ringed seal breeding in the drifting pack ice of the Barents Sea. Mar Mamm Sci 15:595-598 